\title{
京弓における材料技術
}

濱田 泰以*

\section{Materials Technology in Kyoto Bow}

by

\author{
Hiroyuki HAMADA*,
}

Production technology in traditional industries is inherited in the form of " remember while watching the back of the master." It is a knowledge base of the form of "tacit knowledge", and they need to be formalized by the power of science and technology. Movement of experts is recorded using an infrared camera. The position in the space of the marker affixed to each part of the body of the subject is acquired as digital data.

In this report, Kyoto bow showed examples that formalized the tacit knowledge of manufacturing in traditional industries. Kyoto bow is a Japanese bow often used for archery enthusiasts. Mr. Shibata is the 21 st bow priest. In order to elucidate the tacit knowledge, he possessed, vibration tests and bending tests were conducted. Test results proved that materials with high modulus of elasticity were chosen when Mr. Shibata chooses materials.

\section{Key words:}

Tacit knowledge, Kyoto bow, Vibration tests, Bending tests

\section{1 はじめに}

京弓は弓道愛好家によく使われている日本の弓である. 現在, 柴田勘十郎氏が京都で京弓づくりを手掛けており, 筆者らは柴田氏との共同研究 ${ }^{1,2)}$ を通して, 京弓のものづ くりにおける暗黙知を形式知化してきた。研究過程で得 られた数々の知見を精査する中で，現在のものづくりに も有効な示唆が多く含まれていることが明らかになった。 本稿において，その一端を披露する.

我々は伝統産業におけるものづくりに注目し，「師匠の 背中を見ながら覚えなさい」という形式で継承される「暗 黙知」という形の知識ベースを，科学技術の力で形式知 化していく研究活動を行っている.「伝統産業工学」と称 し，大学内においては「伝統みらい教育研究センター」 という組織も立ち上げている。

形式知化のための手法としてはまず，ものづくりの工 程を分析寸る，工程はいくつあるのか，また，それぞれ の工程の名前, それぞれに必要な時間, 使う道具などを 調べる．案外，この工程分析を行うことにより，技能の 伝承が容易になることが多い，名前を付けることで共通 の言葉が存在することになり，作業時間が分かるともの づくり全体の予測が可能となるからである．伝統産業の ものづくりは手作業によるところが多いので，工程分析 に続いてものづくりの動作解析を行なう。我々は赤外線 カメラを用いて体, 腰, 腕, さらに指の動きなどのデー タを採取している．体に貼りつけたマーカーの空間での
位置を, デジタルデータとして取得するのである。一旦 そのデータが得られると, 速度, 加速度と次々に必要な データを算出することができ, 最近では加加速度を使っ て評価することも始めている，もっと詳しく動きを調べ たい時には, 高速度カメラを導入する.

ものづくりの作業中に作業者はどこを見ているのか. そうしたデータを得るためには眼球運動解析を行なう。 匠はどこを注視しているのか. 手元なのか, 次の作業場 所なのか，それとも作業終了の場所を確認しているのか などについては，匠に訊㸚ても答えが得られることは少 ない。なぜなら，ものづくりのコツが既に体に浸夕込ん でいるので，敢えてそれを説明することには困難を伴う ことが多いからである.

そこで目の動きのデータを取得し，それを匠に説明し た後に，解説してもらうという手法で，しばしば暗黙知 の所在を探る。眼球運動の取得には, ゴーグルタイプの 装置を着けて行うことが多い. 作業環境が劣悪な場合や ゴーグル装着が作業の邪魔になる場合などではウエブカ メラを装着し，得られた画像を再生して画面上で視線を 解析する手法が有効である。これには視線計測装置が必 要となる。この手法を使えば，共通の動画に対して異な った人の視線を調べ，比較できる点にメリットがある. また, ものづくりの過程における力の程度や配分などを 調べる際には，把持力計やフオースプレートを用いる.

そのほか，作業者の生理的反応を見るために心拍数や

$\dagger$ 原稿受理 平成29年7月10日 Received July 10, 2017

(C)2017 The Society of Materials Science, Japan

* 正 会 員 京都工芸䋊維大学 伝統みらい教育研究センター † 606-8585 京都市左京区松ヶ崎御所海道町 Advanced Fibro-Science, Kyoto Institute of Technology, Sakyo-ku, Kyoto, 606-8585. 
脳波を採ることもある．目標とするものづくりをよく観 察して，匠とコミュニケーションをとり，採取すべきデ ータを決めていくことが肝要である。もちろん，伝統産 業の保存と継承に向けて，匠が技の公開に積極的である ことが大前提となる。

匠が語る言葉には技の奥義が隠れている，それゆえ， 語り言葉をそのまま記録しておくことも重要な研究テー マとなる．受け手の勝手な解釈で匠の技を理解すると， 技の本質が見えなくなることが多い，そのために匠の語 り言葉をそのまま記録することを「オーラル伝統みらい」 と位置づけて研究手法に加え, 言葉もデータとして取り 扱い，保存することとしている，本稿においては，これ らの手法を用いて, 御弓師・柴田勘十郎氏の語りを中心 に，京弓ぶくりの暗黙知を形式知化した例を紹介する.

\section{2 京弓の構造}

柴田の語り 1

「私が作っている弓というのは日本の弓です．長いので す、私が手を伸ばしてもまだ長いですね. どれだけの長 さになるかと言いますと, 丈の長さで7尺3寸と言うのが 基本です、メートル法に直すとだいたい220センチくらい になるのですが，それが一番基本の長さ，それが並寸っ ていう，常通の長さ，日本の弓というのは世界中にない くらい長くて，ただイギリスにもイングランドロングボ ウという長い弓があるのですが，それもそこそこ2メート ル止まりなのです. それも単弓です. 木で木弓なのです ね. 日本の弓は世界中で一番長くて一番へんてこりんな 弓なんです．なんでおかしな弓なのか．握るとこが弓本 体の真ん中心゙ゃないんです．こんだけ長い弓はどこを探 してもない．ほとんど全部の弓が握るところが弓の真ん 中についていて，上下のカのバランスをとって矢を飛ば します. ところが日本の弓だけがこういうへンテコな弓 になんですね. 他の国の弓というのは単弓なんです．た とえば木一本でできているとか，材料単体でできている んです. 日本の弓の場合は3層構造になっています.」

Fig.1 に京弓と西洋の弓道, アーチェリーの弓の比較を 示す、日本の弓は長いことが分かる。そして軽量である のが特徴である. また，手で持つ場所が，アーチェリー は弓の長手方向の真ん中であるのに対して, 京弓では, 下の方になる．したがって弦を引くと，上の方が大きく 変形することになる．断面は Fig. 2 に示すような貼り合わ せ構造である. 外側の竹と内側の竹との間に「中打ち」 という異なる木材を組み合わせたものが挟み込まれてい る. 京弓は寸べて天然の材料で作られている.アーチェ リーでは同一材料で構成されているのに対して, 京弓は 天然素材を用いたハイブリッド構造であると言えよう. 中打ちと外竹，内竹とは接着剤で㙋り合わせている.

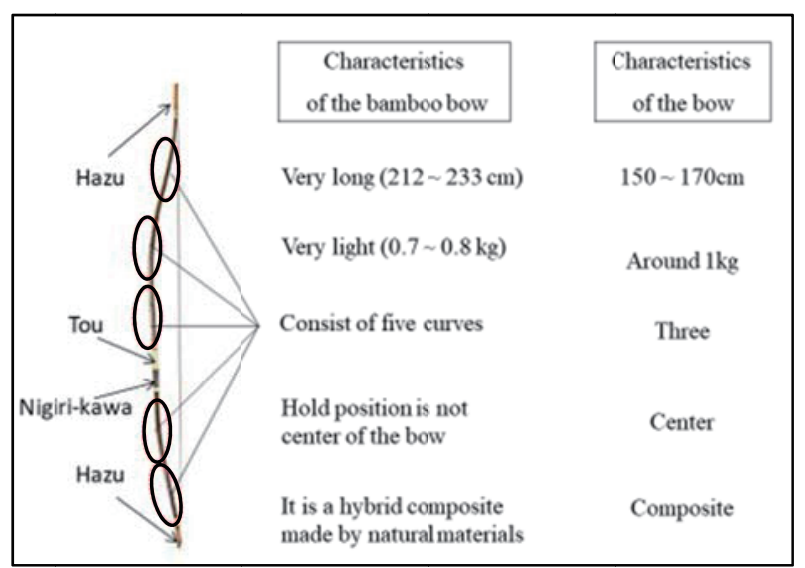

Fig.1 Characteristics of Kyoto bow and bow.

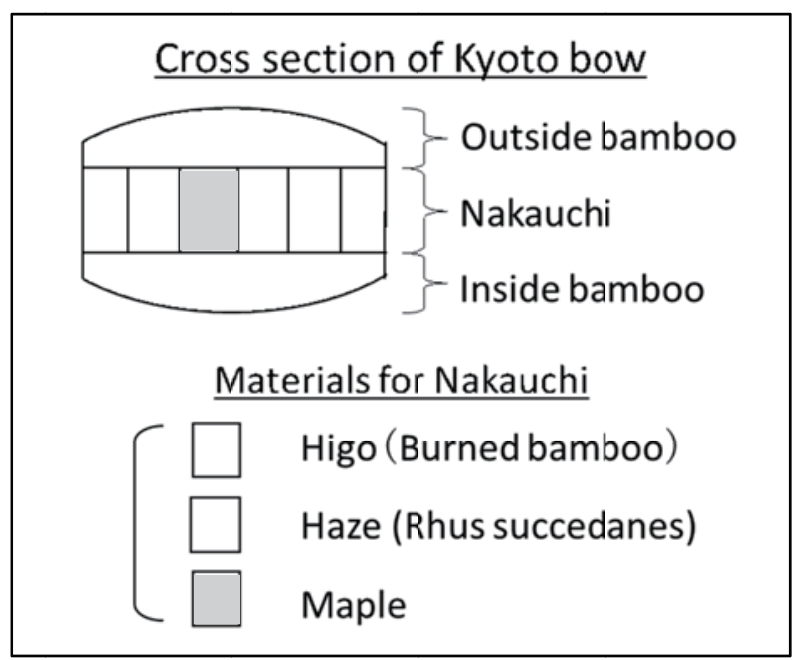

Fig.2 Structure of Kyoto bow.

それぞれの素材の物性を曲げ試験により求めた．竹の 厚みがおよそ $5 \mathrm{~mm}$ であったため， $\mathrm{L} / \mathrm{H}=16$ によりスパン 間は $80 \mathrm{~mm}$, 中打ちの構成材料であるヒゴ・八ゼ・メープ ルもそれに合わせ，厚さ $5 \mathrm{~mm}$ ，スパン間 $80 \mathrm{~mm}$ ，クロス ヘッド速度 $50 \mathrm{~mm} / \mathrm{min}$ で三点曲げ試験を行った. Fig.3に, ヒゴ・メープル・八ゼの 3 種類についての曲げ応力-たわ み線図を示す，八ゼは破断に至るまでの荷重が直線的で 破断ひずみも小さいため脆性であり，ヒゴ，メープルは 八ゼに比べて破断ひずみが大きくなっている.

八ゼはメープルに比べ脆性的で，これは「八ゼは硬く 脆い, メープルは粘い」という柴田氏の暗黙知と一致し た。一方「硬く脆い」ヒゴは脆性的ではなく, 柴田氏の 発語や見立てとは異なる結果せなった. Fig.4 に, 厚さ $5 \mathrm{~mm}$, スパン間 400mm, クロスヘッド速度 $1 \mathrm{~mm} / \mathrm{min}$ での曲げ 試験より得られた外竹と内竹の弾性率を示す。外竹と内 竹を比較すると, 曲げ弾性率逖内竹の方が高いことがわ かる、スパンの短い曲げ試験では確認できなかった両者 の特性の違いを見ることができる. 


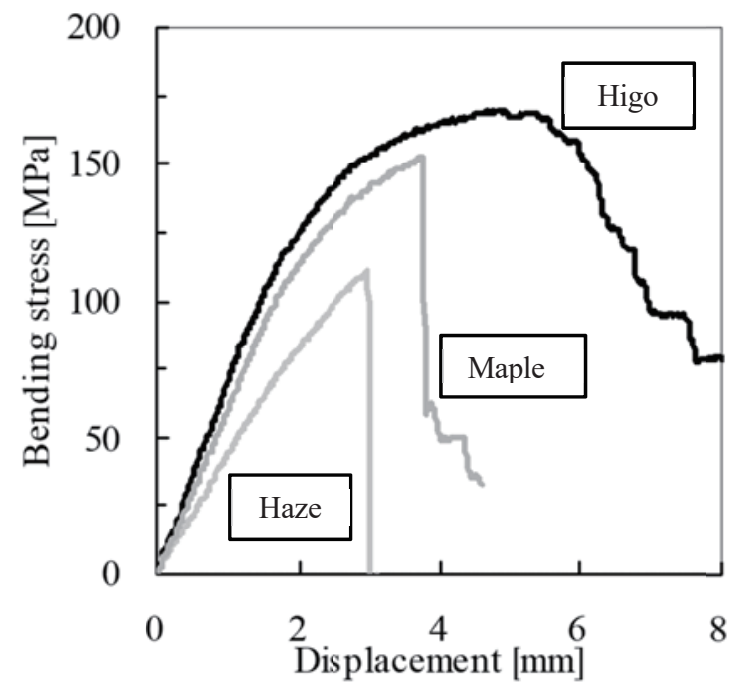

Fig.3 Relationship between bending stress and displacement.

20

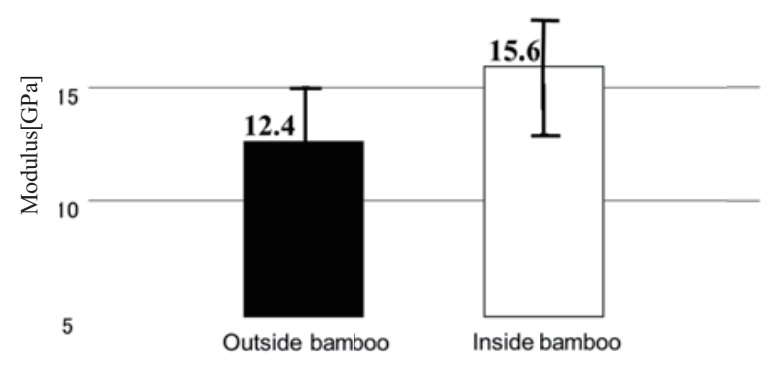

Fig.4 Modulus of elasticity of inner and outer bamboo.

\section{3 京弓に使う竹}

\section{柴田の語り(2)}

「私が住んでいるところは, 戦前, 明治の幕末ごろま では弓座があったんです，弓座って組合がありました． 何十軒という弓屋さんがあって, 京都というのはかなり 弓の産地としては昔は有名なとこだったんですね. どう してかと言うと, 京都の特に西のほうは竹林がものすご く多いんです．弓になる材料の竹というのは真竹なんで す．そんなに大きい真竹ではないです．だいたい使う真 竹の直径は 6 センチくらいです．竹の大きさは直径で呼 ばないんですね． いびつな部分もありますので，外周で 大きさを言うんです．直径で 6 センチくらいと言います と, 尺貫法で言いますと, 2 寸なんですけど, 外周がそれ に 3 かけますんで 6 寸, 6 寸と言いとだいたい外周が 18 センチ, 6 寸竹というものを使います. 京都の竹というの はこれがまた弓屋泣かせなんですわ. 纎維密度が非常に 高いんです．硬いんです．粘りがあるんです，ものすご く我々は削ったり加エするのに苦労するんです，一枚の 竹の厚みは 1 分 5 厘しかないんです. 1 分 5 厘とは 4.5 ミ リなんです，かなり削りこんでしまわないと駄目なんで
す．なぜそこまで薄く削り込むかと言いますと，竹とい うのは表皮に近いとこほど繊維密度が高くて繊維がよく しまってるんです．内側というのはそんなに繊維が締ま っていないのでできるだけ繊維密度が高いところだけを 使用するために薄く薄く削ります.」

このような暗黙知を解明すべく，振動実験を行なった。

Fig. 5 に実験模式図を示す。長方形の断面 $(23 \times 3.3 \mathrm{~mm})$ を有する竹，これはすでに柴田氏より外竹用と内竹用に 区別されているものを，長さ $140 \mathrm{~cm}$ として一端を固定し た. その上で自由端を $50 \mathrm{~cm}$ たわませて放すことにより振 動を与えた. 振動状態の計測には, 1 秒間 250 フレームの 速度で撮影が可能な高速度カメラを用いた。

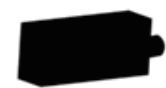

High speed camera

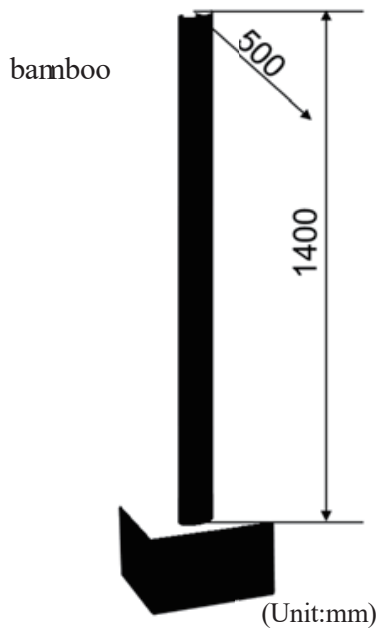

Fig.5 Position relationship between bamboo and camera.

Fig. 6 は，振動実験の結果である。この図の縦軸は自由 端の変位であり，横軸は時間である．50 cm のところから スタートして，変位がマイナスになり，またプラスにな るという振動現象である。周期を見ると内竹の方が短い ことがわかり，これは弾性率の高いことを示している. 一方, 振動の山の下がり方を見ると, 内竹, 外竹ともに 同じである，これは減衰特性が同じであることを示し， 粘性特性は両竹において差がないことがわかる.

つまり，竹を振動させることによって，弾性の違いを 調べていることになる. Fig. 7 は，竹の断面写真である. 硬い繊維の部分の量は外竹が $9 \%$, 内竹が $18 \%$, 柴田氏 が選んだ竹の内竹は䋊維の量が多い. Fig. 8 からわかるよ うに, 弾性率とその䋊維の量の関係を見ると, 竹の弾性 率は繊維の量に比例している。柴田氏は内竹に繊維の量 が多い，すなわち弾性率の高い材料を選んでいることが わかった。 


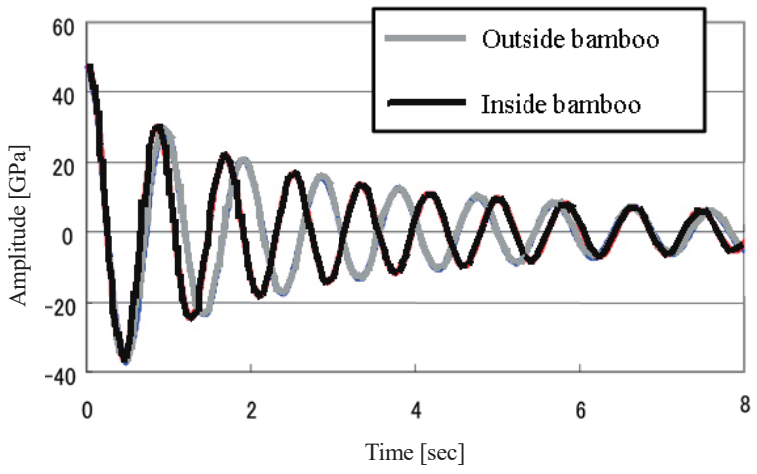

Fig.6 Results of Vibration tests Outside and Inside bamboo.
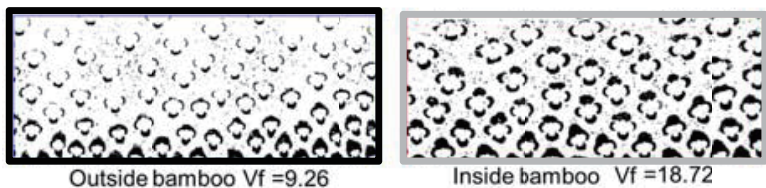

Fig.7 Cross-sectional picture of binary bamboo.

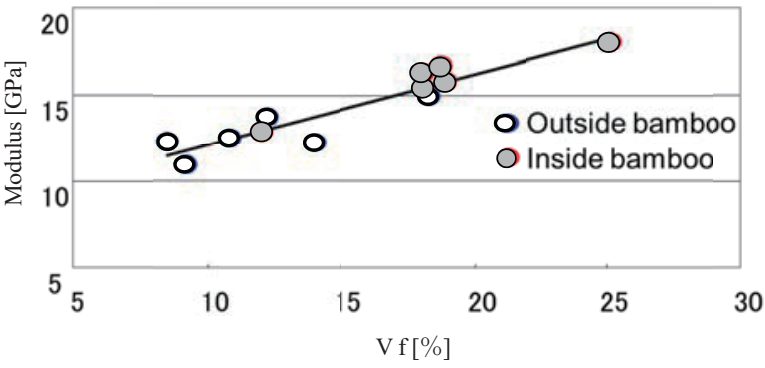

Fig.8 Relationship between elastic modulus and fiber content.

\section{4 京弓に使う接着剂}

柴田の語り(3)

「昔の弓道をされる年配の方は，家の店に来て「弓を 作ってくれ」とは言われないですね.「弓を一張り，打っ てください」って言われます. なぜ弓を打つというかと， 縄を巻いて杭を打ってこの形を作るところが一番弓の生 命線なんですね. その生命線が弓打ちと言うことで, 弓 を生産すると同じように言葉で表して弓を作ると言うこ とを弓打ちと言います．縄を巻いた下に楔を打ち込んで 締め上げながらそりをつけていきます，接着剤を乾燥し てから，張り込み，弦を張りますね．今合成接着剂をよ く使いますが，「ニべ」と言いまして，鹿の皮をことこと と炊いて作る接着剂です．この接着剂が「ニベもなく断 る」という言い回しありますね，これの「ニベ」なんで す.「ニベ」というのはこてこてで粘りがあるのですが, 「ニベもなく断る」というのは門前払いばっかり断って しまうということ．堅い皮を水に浸した物を，ぶよぶよ になった物を 3 日 3 晚炊き込むとこういう風になります. 固まるのは温度が冷えるとすぐに固まってしまいます．
接着剂を付けて仮合わせて縄を巻いて楔を打ち込むとき は真剣勝負です.」

ここでは，接着剤の違いが戸の特性にどのような影響 を及ぼすのかを検討した。まずは，矢の速度の測定を行 った。射手の正面に設置したハイスピードカメラにて撮 影した画像を用いて画像解析を行い，各弓から放たれる 矢の速度の算出を行なった. Fig. 9 に矢の速度変化の典型 例を示す. 各被験者において, 二ベ弓および合成弓使用 時で，矢の最高速度にはほとんど差がないことが分かる。 また, ニベ弓より放たれた矢のほうが, 後半で急激に加 速する傾向が見られた。この傾向について，二べ弓およ び合成弓間で詳細に検討を行うために，各弓から放たれ た矢の速度変化を平均化した。平均化された各弓の矢の 速度変化を Fig 10 に示す。

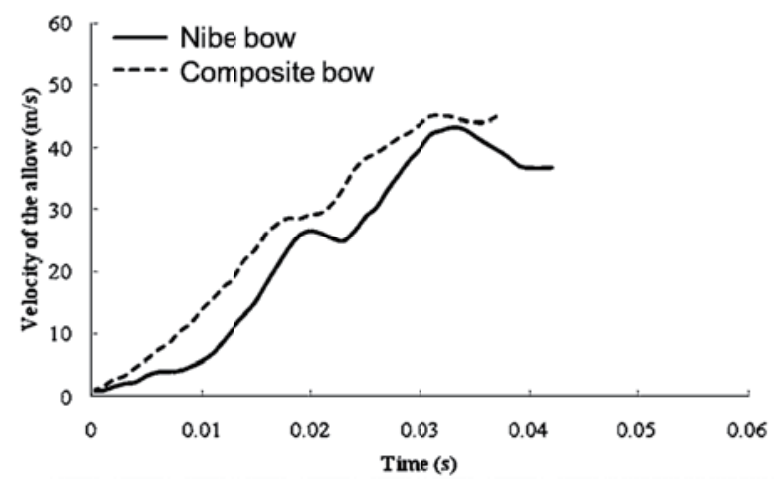

Fig.9 Typical examples of arrow speed changes.

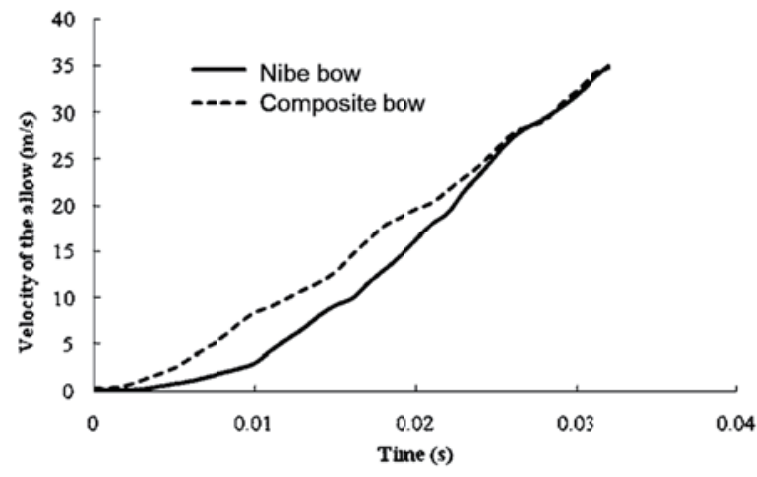

Fig.10 Speed change of arrow of each bow.

ニベ弓から放たれる矢の速度は，射手が弦を離してか ら 0.027 秒後には合成弓から放たれる矢の速度と同じ值 を示すことが分かった. 矢の加速度変化について詳細に 検討するために，時間区間を 0.01 秒ずつの区間に分け， 各々の時間区間における加速度について検討した. 各時 間区間内における矢の加速度の平均值を Fig.11 に示す。 合成弓から放たれる矢の平均加速度には急激な増加は見 られないのに対し，二心゙弓から放たれる矢の平均加速度 は, 0.01 秒後から急激に増加し, その後は合成弓の平均 
加速度を上回ることが分かる。このことから，二べ弓は 合成弓と比べ，矢が弦から離れる直前に，矢に対して推 進力を与え易い弓であることが示唆された。

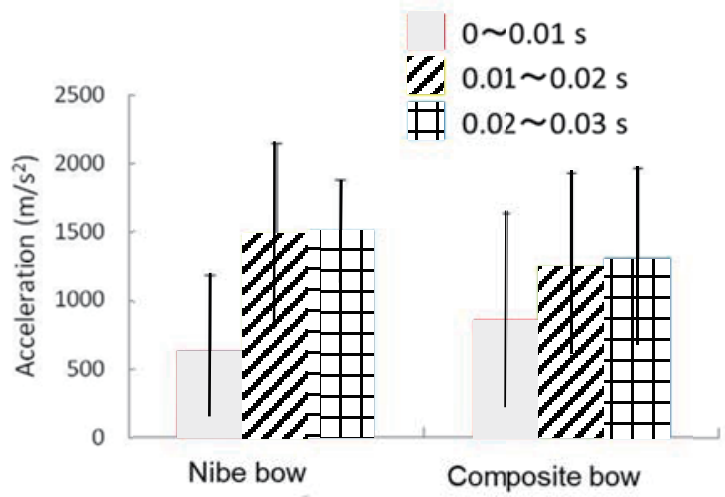

Fig.11 Average acceleration of arrow of each bow.

\section{5 おわりに}

本稿においては伝統産業のものづくりの暗黙知を形式 知化した例を，京弓を用いて示した。柴田氏は御弓師 21 代目である. 長い歴史に裹打ちされた材料選択眼や技術 には多くの先人たちの知恵が注ぎこまれている.まさし くものづくり玉手箱である，今を生きる我々はそれを理 解して，今のものづくりに応用することが可能である。 その際には，先人たちの努力に敬意を払って取り組むこ とが肝要であろう。

\section{参 考 文 献}

1) K. Shibata, S. Nasu, M. Kume, A. Nakai and Y. Hamada, "Relationship between Deformation Behavior and Load of Kyoto Bow in Difference of Adhesive", Dynamics \& Design Conference 2009, "422-1"-"422-4", (2009) .

2) Y. Hidekuma, A. Ohnishi, M. Shirato, M. Kume, A. Nakai and K. Shibata, "Muscle Activity of Drawing the Bow with Kyoto Bow", Dynamics \& Design Conference 2007, "144-1"-"144-4", (2007). 